\title{
Europe abhors Donald Trump. The opinion on the 2020 US presidential elections and their candidates in the European newspapers
}

\author{
Sintes-Olivella, Marçal. \\ Blanquerna School of Communication and International Relations. \\ Ramon Llull University. \\ marcalso@blanquerna.url.edu
}

\section{Franch, Pere.}

Blanquerna School of Communication and International Relations.

Ramon Llull University.

perefp@blanquerna.url.edu

\section{Yeste-Piquer, Elena.}

Blanquerna School of Communication and International Relations.

Ramon Llull University.

elenayp@blanquerna.url.edu

\section{Zilles, Klaus.}

Blanquerna School of Communication and International Relations.

Ramon Llull University.

klausz@blanquerna.url.edu

What is the opinion held by the European press on the US election campaign and the candidates running for president? What are the predominant issues that attract the attention of European print media? Does Europe detest Donald Trump? The objective of the present study is to analyze the perception European commentators had of the 2020 race for the White House. The media, the audience, and European governments were captivated more than ever before by how the US election campaign unfolded, fixing their gaze on the contest between Donald Trump and Joe Biden. Through a combined quantitative and qualitative methodology, a combination of content analysis and the application of framing theory (hitherto scarcely applied to opinion pieces), our research centers on exploring the views, opinions, and analyses published in eight leading newspapers from four European countries (France, Germany, Spain, and the United Kingdom) as expressed in their editorials and opinion articles. This study observes how the televised presidential debates were commented on, interpreted, and assessed by commentators from the eight newspapers we selected. The goal was to identify the common issues and frames that affected European public opinion on the US presidential campaign and the aspirants to the White House.

Key words: Trump, Biden, presidential campaign, press, Europe, content analysis, agenda-setting, framing.

\section{Introduction}

The US general elections, which were held on November 3, 2020, generated great expectations in Europe, both in the media and among European citizens and their governments. Traditionally, this is nothing new. This time around, however, the race for the White House featured an element that made this a vastly different contest compared to previous elections, Donald Trump.

His idiosyncratic personal style, and the politics he pursued domestically and internationally immediately caught Europeans' attention. The unpredictable and confrontational nature of Trump's conduct and demeanor, compounded by his populist communication style, perturbed and alarmed Europe's major government leaders. Although most European countries have grown used to populist parties in their parliaments, mostly on the far right of the spectrum and in minority positions, there arose a growing concern over what Trump's leadership of the most powerful democracy on earth would hold in store.

Donald Trump's singular personality, which defines his conduct as President, has been at the center of several biographies (Leonnig \& Rucker, 2020; MacGregor, 2019; Stelter, 2020; Trump, 2020; Wolff, 2018, 2019; Woodward, 2018, 2020). Joe Biden, with a political career that spans a period from the early 
Sintes Olivella, Marçal; Franch, Pere; Yeste-Piquer, Elena; Zilles, Klaus. Europe abhors Donald Trump.

The opinion on the 2020 US presidential elections and their candidates in the European newspapers. American Behavioral Scientist, 2021. April 2. https://doi.org/10.1177/00027642211005534

seventies until the present day, has two biographies written about him, and his autobiography, Promises to Keep: On Life and Politics, was published in 2008.

In her 2018 New York Times bestseller, Fascism: A Warning, former Secretary of State, Madeleine Albright, calls Donald Trump "the first antidemocratic president in modern U.S. history", tracing the similarities of Trump's ideology and political and communication style with the European far-right populists and with European fascism of the 1920s and 30s.

In view of Trump's particular character and personality, Europeans became increasingly distressed by his vision of international politics, and above all, US policies that have an impact on the values and interests of "the Old Continent", namely international commerce (Janusch, 2017; Koeth, 2019; Welfens, 2019) and the transatlantic military alliance (Burns, 2019; Polyakova, 2019; Sperling, 2019). Similarly, European governments reacted with shock and dismay to Washington's unabashed support of the UK's decision to leave the European Union (Norris, 2019; Wilson, 2017).

Europe looked on in disbelief as Trump's White House called into question, and in many cases effectively withdrew from, multilateral agreements, forums, and organizations such as the UN, the WHO, the Joint Comprehensive Plan of Action (JCPOA) and its negotiation with Iran, policies on Israel, and in particular the Paris Agreement on climate change (Kemp, 2017; Jotzo, 2018; Urpelainen, 2018).

The present study aims to provide insight into how the most influential European quality newspapers scrutinized and commented on the 2020 US elections campaign, which pitted the candidates Donald Trump and Joe Biden against each other.

Our research centers on the content of opinion articles published in the European print press which express their views on the two candidates and their performance during the perhaps most crucial stage of the campaign, namely shortly before and after the TV debates of the presidential candidates.

\subsection{Three Media Systems}

In their pioneering, insightful study, Comparing Media Systems, Hallin and Mancini (2004) posited the existence of three major media models, to which they attributed distinct characteristics. We find that the foundational work done by Hallin and Mancini continues to be fully applicable and operative, despite the radical changes the media industry has gone through since, and which has resulted in the current hybrid media environment (Chadwick, 2013).

The first of the models described by Hallin and Mancini is the "Mediterranean or Polarized Pluralist Model". It is characterized, among other attributes, by low circulations numbers, featuring an opiniondriven journalism, and an elevated degree of political parallelism, which the authors identify as the degree in which contents in different media correlate with the various political and partisan options on offer in each country. Additional features of historical significance are political partisanship, organizational connections between media and political stakeholders, as well as the tendency of members of the media to be political actors or advocates (Hallin \& Mancini, 2004, pp. 26-30).

The second model identified by Hallin and Mancini is the "Northern European or Democratic Corporatist Model", which stands out for its high newspaper circulation, elevated external pluralism (media with different ideological/political perspectives within one media branch), and solid professionalization of journalism.

The third model is the "North Atlantic or Liberal Model", which is characterized by medium newspaper circulation, information-driven journalism, strong professionalization, and a media environment that is driven by the market as opposed to interventional activity by the state.

Both France and Spain are considered as belonging to the first model, whereas Germany is an exemplar of the second model, and the UK belongs to the third model, the "North Atlantic or Liberal Model," which is also the ruling media paradigm in the US, Canada, and Ireland. Our study is predicated on the quantification of certain content elements in the opinion articles and editorials which were published in the eight European newspapers during a specific period before and after the presidential debates (see methodology), and our methodology draws in the main on the well-established analytical models of agenda-setting and framing. 
Sintes Olivella, Marçal; Franch, Pere; Yeste-Piquer, Elena; Zilles, Klaus. Europe abhors Donald Trump.

The opinion on the 2020 US presidential elections and their candidates in the European newspapers. American Behavioral Scientist, 2021. April 2. https://doi.org/10.1177/00027642211005534

\subsection{Agenda-setting}

Agenda-setting theory submits that there is a causal relationship between the importance the media attribute to certain issues and persons, and the importance the audience attributes to the same issues and persons. Thus, agenda-setting theory determines what is being reported, whereas framing theory deals with how news is reported to the audience. One of the precursors of agenda-setting theorists, Bernard C. Cohen (1963, p. 13), observed that the press "is stunningly successful in telling its readers what to think about".

The first traces of agenda-setting theory can be found as early as 1922 in Walter Lippman's Public Opinion, in which the author establishes the foundational link between the media narrative and the representation of events in the world which drives how citizens think and act with respect to reality. Maxwell McCombs and Lei Guo, two of the founding fathers of agenda-setting theory, emphasize that the title of the first chapter of Public Opinion- "The World Outside and the Pictures in Our Heads"-, Lippmann (1922, p. 3) "succinctly identified the setting for the news media's role in the formation of public opinion" $(2014, \mathrm{p}$. 251).

The work which is considered a benchmark in agenda-setting theory is the so-called Chapel Hill Study, which was conducted at the University of North Carolina at Chapel Hill during the 1968 presidential election campaign. The purpose of this study was to provide empirical evidence that showed that the media set the agenda of the political campaign by making certain issues especially salient for their readers and voters. In their writings, McCombs \& Shaw (1972) dismiss the possibility that the causal relationship between the issues reported by the media and the salience perceived by the readers could also work in the opposite direction.

A year after the Chapel Hill study, Ray Funkhouser (1973) published a study spanning the entire United States throughout the decade of the 1970s. Subsequently, a plethora of research projects on agendasetting emerged, deploying different methodologies, focusing on different geographical regions and media environments. Indeed, many studies center on both the pre-election period and the entire political cycle. Furthermore, the impact of agenda-setting on the audience across time is scrutinized and analyzed. McCombs' 2004 book, Setting the agenda. The Mass Media and Public Opinion, epitomizes the kind of research conducted on agenda-setting. McCombs acknowledges that at the time his book came outsome four hundred studies had been published on the subject of agenda-setting.

Agenda-setting, like framing theory, is predicated on the mechanism through which the human brain retrieves and processes information. By foregrounding certain issues, the media, whose impact is caused above all by joint, aggregated action, facilitates the retrieval of information in the audience's memory (Iyengar, 1990).

\subsection{Framing}

Framing theory continues to be hotly debated in academic circles. Numerous scholars have stressed the challenge of establishing a clear, integrated, and shared model. Attempts have failed at translating the concept of framing into a methodological framework which delimits, as far as this is conceivable, the element of subjectivity inherent in the conceptualization of framing theory.

Framing theory has found its way into many academic disciplines, not the least of which is the field of psychology, where the works of Daniel Kahneman have made a significant contribution. Similarly, in sociology, the discipline of the present study, the pioneering work was carried out by Erving Goffman (1974).

Among the many definitions of framing, we have chosen Entman's classical definition, as it best suits our purposes. Entman contends that

"To frame is to select some aspects of a perceived reality and make them more salient in a communicating text, in such a way as to promote a particular problem definition, causal interpretation, moral evaluation, and/or treatment recommendation for the item described" [original italics] (1993, p. 52). 
Sintes Olivella, Marçal; Franch, Pere; Yeste-Piquer, Elena; Zilles, Klaus. Europe abhors Donald Trump.

The opinion on the 2020 US presidential elections and their candidates in the European newspapers. American Behavioral Scientist, 2021. April 2. https://doi.org/10.1177/00027642211005534

The words and images which produce the frame may be distinguished from the rest of the news through their capacity to generate support or opposition toward one of two or more parties involved in a political conflict.

The potential to influence the audience may depend on the use of more culturally resonant terms, as well as on their magnitude, which is defined as the prominence and repetition with which the media treats the respective issues (Entman, 2003). Entman adds that the news frames must meet at least two of the following conditions: a) defining effects or conditions as problematic; b) identifying causes; c) conveying a moral judgment of those involved in the framed matter, and d) endorsing remedies or improvements to the problematic situation (2003, p. 417).

Thus, the framing effect relies on the perspective, the point of view, from which an issue or an individual is presented and defined by utilizing a series of definitions and arguments. The media, through framing, provide the audience with patterns or blueprints designed to condition their assessment and interpretation of issues and people. The frames employed by the media have the capacity to activate patterns of interpretation, conceptual matrixes, or cognitive networks, which condition the way audiences interpret contents.

As Sniderman and Theriault (2004) affirm, on many occasions audiences are not exposed to one single frame shaping an issue. Rather, they find themselves in an environment in which diverse frames on a single issue are in competition with each other. What is more, frames display a dynamic nature; indeed, they evolve and transform with the passage of time, given that they are the fruit of social interaction.

McCombs and other theorists have argued that framing is in fact an extension, or the equivalent, of the socalled second level of agenda-setting or attribute agenda-setting. (Lang \& Lang, 1981; McCombs, 2004; McCombs \& Ghanem, 2001; McCombs, Llamas, López-Escobar \& Rey, 1997). By contrast, scholars such as Price \& Tewksbury (1997) and Scheufele (2000), among others, claim that the opposite is true. As Ardèvol-Abreu (2015, p. 427) points out, for the time being there is a consensus that agenda-setting theory and framing theory are autonomous despite their proximity and complementary nature.

\section{Hypothesis}

The principal objectives of this study are twofold. Firstly, we seek to examine the attention the European press paid to the US election campaign, and, more narrowly, which main issues the European press homed in on. Secondly, we strove to ascertain how the European dailies estimated the presidential candidates. To this end, we formed four hypotheses:

H1: Among the European media, the British devotes the greatest attention to the presidential candidates, Trump and Biden.

H2: The European newspapers we analysed take an unequivocally unfavorable tone towards

Trump, whereas Biden receives a more favorable coverage.

H3: The prevailing frame characterizes Trump as a politician with a radical, thuggish communication style who seeks to stoke the division of American society.

H4: The agenda of the European newspapers we examined prioritizes issues revolving around international relations, and in particular, US-European relations.

\section{Methodology}

This study analyzes opinion articles by individual commentators as well as editorials expressing the editor's opinion. We limited our sample to articles published in eight daily newspapers from four countries: France, Germany, Spain, and the United Kingdom, as these countries have the largest populations and the greatest Gross Domestic Product (GDP) among the European countries. The country with the largest population and greatest GDP is Germany, followed by the United Kingdom, France, with Spain occupying the fifth place. The fourth largest country is Italy, which is not included in our study.

The focal point of our observations are the opinions voiced in the European press on the two debates that were televised on 29 September 2020 in Cleveland (the morning of October 30th, central European time), and in Nashville on October 22 (the morning of October 23, European time). The two time periods for which we gathered our sample span the period from 29 September to 6 October 2020 for the first debate, and 22 to 29 October (all Central European dates) for the second debate, first and last dates included 
Sintes Olivella, Marçal; Franch, Pere; Yeste-Piquer, Elena; Zilles, Klaus. Europe abhors Donald Trump.

The opinion on the 2020 US presidential elections and their candidates in the European newspapers. American Behavioral Scientist, 2021. April 2. https://doi.org/10.1177/00027642211005534

The eight European daily newspapers we chose for our sample were the French Le Monde and Le Figaro, the German Die Frankfurter Allgemeine Zeitung and Die Süddeutsche Zeitung, the Spanish El País and El Mundo, and the British The Times and The Guardian. The criteria according to which the selection was made are a) All of these publications are influential quality newspapers which are deemed representative of each country's mainstream spectrum of opinions; b) The traditional weight these publications carry in the historical context of their respective societies; c) Readership and circulation. Further to readership and circulation: El País and El Mundo occupy the top two positions in Spain, (AIMC, 2020). The same holds true for Le Monde and Le Figaro in France (ACPM, 2020). In Germany, the Süddeutsche Zeitung and the Frankfurter Allgemeine Zeitung are the newspapers with the second and third largest readership behind the Bild Zeitung, which is not included in this study as it is manifestly a tabloid newspaper with a marked sensationalist editorial line similar to the British The Sun or the Daily Mirror (Thomaß, B.; \& Horz, Ch. nd). In the United Kingdom, The Guardian and The Times occupy the fifth and ninth position in their digital editions (Tobitt, 2020), and they are the print newspapers with the highest circulation that are not considered tabloids, with The Times in first place, and The Guardian in third, behind the Financial Times (Mayhew, 2020).

A further criterion for including these publications in our selection is their political leaning on the ideological spectrum. Thus, Le Figaro, Die Frankfurter Allgemeine Zeitung, El Mundo and The Times are representative of the center-right, conservative position, and Le Monde, Die Süddeutsche Zeitung, El País y The Guardian are considered center-left, progressive newspapers. This selection includes newspapers that constitute examples of the three models of journalism identified and labeled by Hallin and Mancini, as previously discussed in the introduction.

In order to locate all the editorials and opinion pieces we drew on the databases Factiva and MyNews, as well as the newspapers' print editions. A total of 87 articles were found (see results section), which make up the field work sample of our study. It is worth pointing out that in the case of The Guardian two articles were included (one on each debate) that were written by four authors each. We decided to compute these as eight distinct opinion pieces as they convey the individual opinions of the eight journalists.

In order to study the 87 articles, a methodology based on qualitative textual content analysis has been employed (Bardin, 1996; Berelson, 1952; Krippendorff, 2004; Weber, 1990). We study the tone in which each candidate is presented (positive, negative, or neutral); the main arguments put forward in expressing an opinion; the main words and terms used as attributes to describe the candidates as well as the frames that are chosen so that readers interpret the news in the manner suggested by the journalist.

Classifying the tone of a text into positive, negative, and neutral is a frequent practice in content analysis. Lately, this method has seen ample usage in the so-called "sentiment analysis" of texts in social networks, through big data analysis, and artificial intelligence: computer software using algorithms which are able to scan millions of text units (Taboada et al. 2011; Thelwall et al. 2010; Liu, 2010). A precedent for a more qualitative driven study, like the one we have undertaken, would be the study authored by Druckman and Parkin (2005, p. 1.039), who avail themselves of this method in order to explore how the Star Tribune's and the St. Paul Pioneer Press's positioning had an impact on how voters cast their ballots in the Senate elections in Minnesota in the year 2000. Druckman and Parkin, in turn, reference the pioneering study undertaken by Kahn and Kenney (2002) to justify the division into positive, negative, and neutral tone. The tone of an article is considered neutral when the candidate is referenced and neither a negative nor a positive estimation can be inferred. Occasionally, the category "not classifiable" is added when no mention of the candidate is made.

There is an abundance of literature on the effect of framing, as well as agenda-setting, on the political news media. Although there is less literature on how they affect opinion pieces and editorials, several studies, some of them published very recently (Alitavoli, 2020; Garza, 2017; Ha, 2017, 2015; Dahmen, 2010) have applied the concepts and mechanism of framing to opinion articles. Although opinion articles may be by nature subject to framing, this does not obviate the utility of analyzing the practice of framing in text that reflect an individual's opinion. One of the benchmark studies on framing and political news was authored by Semetko and Valkenburg (2000), although they resort to a deductive method parting from five pre-established macroframes: attribution of responsibility, conflict, human interest, economic consequences, and morality. The present study draws on an inductive methodology known as grounded theory, designed for qualitative analysis (notably in anthropology and social phenomenology): through direct observation of the articles to be analyzed the major frames are detected and singled out, starting 
Sintes Olivella, Marçal; Franch, Pere; Yeste-Piquer, Elena; Zilles, Klaus. Europe abhors Donald Trump.

The opinion on the 2020 US presidential elections and their candidates in the European newspapers. American Behavioral Scientist, 2021. April 2. https://doi.org/10.1177/00027642211005534

out initially with a wide, inclusive definition. During the process of analysis, as more distinctive features emerge, the frames are defined more narrowly, and their foremost constituting elements can be delineated. By applying this method, we identified nine key frames (see results section), whose frequency was counted and subjected to analysis.

Once the diverse variables were examined, we analyzed the articles published during the time span we chose for our sample, and finally the common features in the newspapers from each of the four countries emerged. In this manner, we arrived at a global vision of how the European print press viewed the candidates in the debates.

\section{Results}

\subsection{By countries}

\subsubsection{France}

The two French newspapers included in our study dedicated 15 articles to the two TV debates. Their tone is predominantly negative toward Trump, and neutral or positive toward Biden, which is attributable to Le Monde's plainly negative overall appraisal of Trump and its positive estimation of Biden. Conversely, Le Figaro is disapproving of Biden and neutral on Trump.

Most of the six articles in Le Figaro only address domestic US issues, as there are: racism (3) and the Covid crisis (3). Foreign policy is practically absent save one article which deals in a cursory fashion with USEuropean relations and merely mentions China and Russia. Four of the articles reference the two candidates' communication style.

As for the arguments put forth in the articles, those that are disapproving of Trump portray him as a "nationalist-populist" leader who undermines US institutions as well as the international, multilateral policies the US stands for historically. One of the articles holds that "far from making America Great Again, Trump has hastened its decline," (Baverez, 5 Oct. 20). The articles that strike a positive note about Trump present him as a leader who is "strong, energetic, able to take risks", in contrast to a "prudent and responsible" Biden. "Trump, brimming with energy and testosterone, seeks to embody action, strength, risk-taking, and life that is moving forward" (Mandeville, 26 Oct. 20). Conversely, Biden comes across as "more appeasing but also more sluggish. He emanates empathy, responsibility, and caution"(Mandeville, 26 Oct. 20).

Le Monde prints 9 articles, most of which tackle domestic issues: the economy (4), racism (3), the Covid19 pandemic (2), climate change (2), and Amy Coney Barret's nomination to the Supreme Court (2).

The center-left newspaper's editorialists sound the alarm. "Four years of Trumpism have contributed substantially to weakening one of the greatest democracies in the world (...). The president's ambiguity about accepting the election outcome is just as troubling as his refusal to condemn the violence of white supremacists" (Le Monde, Editorial board, 1 Oct. 20).

In terms of the overall opinion on both candidates, Le Monde's foremost arguments are: Trump "indulges" the far right; he denies the systemic racism in US society; he "degrades" and "sabotages" US democracy; he "insults adversaries, stigmatizes the media, lies, and divides Americans"; he "undermines US institutions" and his "honesty" and "credibility" are in discredit. Le Monde expressly homes in on Trump's style of political communication, stating that he is "devoid of scruples" and resorts to "lies", "insults", and "gratuitous accusations and self-glorification."

The American novelist, Richard Ford, (23 Oct. 20), invited by Le Monde to opine on Trump, levels scathing criticism at the President, calling him "a contumacious president stoking public violence and governmental distrust", "a despot", "a proto-fascist or any of the other things he might be - an evil child, a Frankenstein stumbling around in a dark, unfamiliar room (That would be America), or just a Covidaddled, oxygen-deprived, old roid-rager", denouncing Trump's "authoritarianism" further along in his article.

Biden receives a more favorable treatment by Le Monde. In the only article that is slightly disapproving of Biden, the criticism is based on the assumption that as President, Biden's economic relations with Europe 
Sintes Olivella, Marçal; Franch, Pere; Yeste-Piquer, Elena; Zilles, Klaus. Europe abhors Donald Trump.

The opinion on the 2020 US presidential elections and their candidates in the European newspapers. American Behavioral Scientist, 2021. April 2. https://doi.org/10.1177/00027642211005534

will continue to be protectionist, whereas those who give Biden an auspicious assessment, predict that he will give priority to the protection of the environment, that he will seek to reduce greenhouse gases, that he will pursue the welfare of the planet over "America First", and that, unlike Trump, he is committed to accepting the election results whatever their outcome.

The frames we identified as emerging with the highest frequency in the French press are: Trump endangers and diminishes US democracy and its institutions, and he denigrates the reputation of the US abroad (5). Joe Biden is a moderate politician, prudent and responsible, albeit weak, with a strong commitment to US democratic institutions and national reconciliation (5). Next on the list emerges the frame that has Trump contributing to the polarization and division of US society (4), as well as the frame which suggests that Trump's political and communication style is aggressive, populist and mendacious (4). Bringing up the rear, but still rather prominent, is Trump's refusal to disavow white supremacism (3).

\subsubsection{Germany}

With regard to Germany, perhaps the most solid similarity that can be observed in the treatment the editorialists give the two candidates is a general non-committal attitude towards Joe Biden, perhaps even a lack of interest, whereas one of the most significant dissimilarities is the unwillingness, on the part of the Frankfurter Allgemeine Zeitung to condemn Trump irredeemably, while the Süddeutsche only finds one redeemable element in Trump, which is the lawsuit Trump has brought against Google (Kreye, 21 Oct. 2020).

The two major German quality print outlets devote only a total of 15 opinion articles to the two TV debates. Almost all of the articles are at odds with Trump's boorish and clownish style of communication and confrontation, but not all of the articles deny the effectiveness and strength inherent in his approach vis-a-vis Biden's insipid, passive, and feeble performance in the debates, at times even pleading with the moderator to intervene and stop Trump's barrage of attacks and falsehoods. This lack of assertiveness is not a good look for Biden, who after all is aspiring to be the commander-in-chief, and the leader of the most powerful democracy on earth (Ross, 30 Sept. 2020). In contrast, many commentators home in on Donald Trump's character profile and mental state, labelling him variously "narcissist", "demagogue", "on steroids" (after his contraction of the Covid), "anti-books", "anti-intellectuals", "anti-experts", "champion of the uneducated" (all hallmarks of populism), "enabler of racists and climate change deniers", "super spreader of fake news and conspiracy theories", given to "grotesque bragging" and "celebrity bluster", and deflecting any remotely threatening questions.

The German daily Süddeutsche Zeitung dedicated a total of five opinion articles to the two televised 2020 US presidential debates, three to the first debate and two to the second debate. Except for one, all of these opinion pieces in the center-left daily level scathing criticism at the incumbent. By contrast, Joe Biden is mostly portrayed in a neutral fashion, or not mentioned much at all. All of these pieces are signed by individual commentators. There is no editorial that articulates the general editorial line of the Südddeutsche.

Most of the articles foreground Trump's and Biden's vastly different personalities and communication styles (5) and the disastrous way in which Trump ignores, belittles, and politicizes the Corona pandemic, and even his own infection with the disease (4). Other issues that receive heightened attention are racism (2), the pandemic (4), and the economy(4). Supreme court nominations (1), and the allegations of Hunter Biden's business dealings in Ukraine (1) are merely mentioned in passing. Similarly, international politics receive only cursory attention in the cases of China (1) and Russia (1).

Most commentators judge very harschly Trump's incapacity to address pressing issues of national significance, his proclivity for straying off script, and his main debate strategy which is reduced to constant interuptions and ad hominem attacks, mainly by scorning Biden as a fragile, senile weakling (Zaschke, 30 Sept. 2020). Indeed, Trump seems more intent on making himself the center of the debate in what can only be described as megalomaniac showmanship (Zaschke, 30 Sept. 2020). In like fashion, he is censured for his decision to turn his Corona infection into an opportunity to belittle the risks of the disease, scoffing at it, and ridiculing Biden's sensible approach to the disease while stoking the conspiracy theories entertained by many of his followers. (Covid-19 is essentially harmless, it is the result of a secret Chinese scheme, that wearing a face mask is a sign of weakness and anti-Trump and anti-American, and it was, by the way, the Democrats who locked up children in cages). After the second televised debate, Hubert Wetzel invokes the phenomenon of psychological projection in an attempt to explain Trump's 
Sintes Olivella, Marçal; Franch, Pere; Yeste-Piquer, Elena; Zilles, Klaus. Europe abhors Donald Trump.

The opinion on the 2020 US presidential elections and their candidates in the European newspapers. American Behavioral Scientist, 2021. April 2. https://doi.org/10.1177/00027642211005534

compulsion to attribute his own failures, untruths, and destructive obsessions to his opponents. True to character, Trump rejects, off hand, any responsibility for the three major crises currently afflicting the US: the pandemic, the US-wide protests against systemic racism and police brutality, and the catastrophic forest fires on America's West Coast.

Conversely, Joe Biden, the democratic candidate poised to succeed Trump, is generally portrayed as a candidate with very few distinguishing features other than appearing to be a decent, compassionate person, and not being Donald Trump (Zaschke, 30 Sept. 2020). According to the Süddeutsche commentators, Biden's principal strategy, in particular in the second debate, is limited to smiling pityingly as Trump spews his fallacious claims, thus encouraging the incumbent to dig his own political grave. Biden, however, does rise to Trump's bait when his son Hunter Biden is attacked for his activities as a lobbyist in Ukraine. In sum, the editorialists for the Süddeutsche foreground Trump and say relatively little about Biden, as, on the whole, there is not much to sink their teeth into.

The more conservative Frankfurter Allgemeine Zeitung published a total of ten opinion articles on the two debates, seven about the first debate, and three about the second debate. As was the case with the Süddeutsche, the Frankfurter Allgemeine Zeitung did not publish an editorial that articulates the newspaper's general editorial line.

All the articles addressing the first debate are markedly unfavorable for Trump, whereas the articles on the second debate are rather more difficult to categorize "for or against" Trump. Biden does not reap much praise either. Only one article can be classified as unequivocally favorable toward Biden, and only because he had the decency to wish Trump a speedy recovery when Trump's Covid infection became public. The remainder of the articles takes an unfavorable (4), or neutral to non-committal (5) position regarding the Democratic candidate. The issues most widely foregrounded by the editorialists are: the pandemic (9), the two candidates' vastly different communication styles (8), the economy (6), the US healthcare system (3), racism (2), and climate change (2). The supreme court nomination, the investigation into Hunter Biden's activities in Ukraine, and Trump's unwillingness to concede an election defeat received one mention each.

The frames that were the most prominent in the two German dailies were, in order of frequency, Trump's aggressive political and communication style, which leans toward the populist and mendacious (16 mentions); his reckless conduct over Covid-19 (15); Trump stoking polarization and division among US citizens (12); Biden's moderate, prudent, responsible personality and conduct, tending to come across as unassertive yet strongly committed to US democracy and its institutions as well as to national unity and reconciliation (7); and Trump harms and diminishes US democracy and its institutions, and denigrates the reputation of the US (6).

\subsubsection{Spain}

Both El País and El Mundo pay greater attention to President Trump than to Joe Biden. Thus, we find that the tone the articles strike with respect to Joe Biden is neutral or not classifiable in 14 of the 28 articles published in the Spanish press. (out of the 14, 3 were neutral, and 11 not classifiable). By contrast, there are only two articles that strike a neutral tone regarding Trump, and there is no instance of an article that would fall into the category "not classifiable."

15 of the articles in El País display a negative tone toward Trump. As regards Biden, 3 of the articles in $E l$ País are positive in tone and 4 are negative ( 1 is neutral and 5 are not classifiable).

El Mundo issued a total of 13 pieces, the majority of which are disapproving of Trump (10), whereas the rest are positive (1) or neutral (2). As for Biden, only one article is positive, 4 strike a negative tone, 2 are neutral and 6 are not classifiable.

Both newspapers coincide in devoting significant passages to analyzing President Trump's political discourse and his communication style. In El País this occurs on 8 occasions, while in El Mundo there are 12 instances, even though El Mundo published fewer opinion pieces than El País in the same time span. Tallying up the articles in both newspapers, passages raising this issue are featured in 20 of the 28 articles. The President's much criticized impulsive and offensive character received greater coverage in the articles about the first debate, likely owing to Trump's chaotic and far from exemplary performance and conduct at this televised event. 
Sintes Olivella, Marçal; Franch, Pere; Yeste-Piquer, Elena; Zilles, Klaus. Europe abhors Donald Trump.

The opinion on the 2020 US presidential elections and their candidates in the European newspapers. American Behavioral Scientist, 2021. April 2. https://doi.org/10.1177/00027642211005534

One of the harsher, and often reiterated estimations of Trump's behavior is exemplified by this comment: "The debate quickly descended into something resembling a brawl among neighbors, kicked off by a vociferous Trump with a bewildered Joe Biden looking on. Apparently, intimidating and shouting down his rival seems to be the go-to strategy chosen by the President" (De la Serna, El Mundo, 4 Oct. 2020).

Another example of the type of opinions Trump's behavior gives rise to was featured on the pages of $E l$ País (Muñoz Molina, 25 Oct. 2020): “Donald Trump's verbal and body language is that of a wise guy: not the kind of mafiosi dishonestly endowed with intense melodrama by Scorcese or Coppola, but rather the coarse, vulgar mobsters of mediocre existence, which are featured in the sensationalist pictures on the front page of the New York Post, or in the almost documentary-like settings of The Sopranos."

As we have stated previously, El Mundo and El País pay much less attention to Biden than to Trump. A telling example are these lines penned by Francisco G. Basterra in El País (5 Oct. 2020): "Biden does not excite the country. What you see is what you get, a tired man, without charisma, honest, a decent guy; he has been tasked with kicking Trump out, which is not the same as having people cast their ballot out of conviction for Biden who succeeded in this first debate because of the low expectations he came in with.

As regards the pandemic and the healthcare system, El País dedicated 4 articles to these issues, El Mundo 5. These two intertwined issues constitute the second most-featured subject in the Spanish press. What ismore, the likelihood that Trump would not concede the victory to Biden was brought up on 5 occasions, 3 times in El País and twice in El Mundo. International relations and foreign politics hardly deserved a mention in either newspaper.

Casting our attention to the frames that emerge most frequently in the Spanish press, we observe that Trump's populist political discourse and his aggressive and mendacious communication style stand out by far. This particular frame is referenced on 12 occasions, 6 times each in either newspaper. Runners up are Trump's polarizing and divisive nature (9), Biden's moderation, prudence and sense of responsibility, his lack of assertiveness but firm belief in American democracy, its institutions, and bringing the nation together (9), as well as Trump's reckless conduct over Covid-19 (3).

\subsubsection{UK}

The British newspapers we analyzed have devoted a total of 29 opinion pieces, 4 of which are editorials. Most of them strike a negative tone vis-à-vis Trump, and a positive or neutral tone regarding Biden.

Concerning issues of domestic politics, the British newspapers highlight the government's management of the pandemic (18 articles), the candidates' distinct political and communication styles (17), and the crisis caused by racial tensions in the US (13). Other prominent aspects are the revelation that Trump only paid $\$ 750$ in federal income tax in 2017 (7), the US economy (8), and Trump's refusal to commit to accepting the election results (6), among others. In terms or foreign policy, relations with China (5) and Russia (4) are mentioned most often. Both The Guardian and The Times dedicate one article each to US-British diplomacy.

Turning our attention to The Guardian alone, we observe that a total of 24 opinion pieces have appeared, 2 of which are editorials. Out of 24,23 judge Trump unfavorably, while 5 strike a positive tone toward Biden, 5 remain neutral and 3 are negative.

During the time span we analyzed, The Guardian devoted most of the articles on the presidential debates to the pandemic (16), to the candidates' political and communication styles (14), and to the racial tensions (11). Other issues that arise frequently are Trump's income tax (7), the economy (6), the US healthcare system (4), Amy Coney Barrett's Supreme Court nomination (4), Trump's refusal to accept the election results (4), the accusations brought against Hunter Biden (4), and climate change (4). Lesser attention was given to foreign policies and international relations, with only 3 mentions, 2 to Russia, and 1 to USBritish relations.

Cas Mudde (28 Oct. 2020) deplores that "Trump's incompetent Covid-19 response has pushed the reputation of both him and the US even further down". In an editorial published on 5 October, The Guardian augurs that "his persistently reckless conduct over Covid-19 will incur an unavoidably high political price". Also damaging for the President is the criticism of his performances in the televised debates. The Guardian (2 Oct. 2020) sharply censures the President's conduct during the first debate. 
Sintes Olivella, Marçal; Franch, Pere; Yeste-Piquer, Elena; Zilles, Klaus. Europe abhors Donald Trump.

The opinion on the 2020 US presidential elections and their candidates in the European newspapers. American Behavioral Scientist, 2021. April 2. https://doi.org/10.1177/00027642211005534

Trump "lied, he blustered, he harangued and, above all, he interrupted", seeing that "he does not accept the rules of the election any more than he accepted those of the debate". Other articles dub Trump a "TV celebrity" and they call his person and his demeanor "belligerent, absolutely horrible", as well as "ineducable, impervious to shame, guilt or any sense of personal responsibility, unaffected by anything except vanity, selfishness and reckless self-regard" (Prose, 6 Oct. 2020).

About the racial tensions, Renton (1 Oct. 2020) avers that "Trump is wrong to pretend that the left is responsible for the violence on America's streets", while Green (30 Sept. 2020), characterizes Biden as "a reality-based, non-conspiratorially minded politician who is opposed to white supremacy and committed to our basic national institutions and the continuation of American democracy".

Likewise, most articles take a positive (5) or a neutral (5) stance toward Biden, commending him for being "competent and honest, appealing for unity", "cautiously responsible", and capable of countering Trump's attacks "with relative aplomb" and "with refreshing candor". And yet, in The Guardian's assessment of the first debate (2 Oct. 2020), Biden "failed to make an impact on issues including the revelations of Mr. Trump's astoundingly low tax payments and the future of the supreme court".

Out of 5 articles in The Times, 4 issue a negative appraisal of candidate Trump, and only one stays neutral. Biden gets off slightly better with two articles out of four striking a positive note, one disapproves, and one stays neutral. Among the issues that receive heightened attention the candidates' respective political and communication styles are featured most frequently (4), followed by racism (2), the economy (2), Trump threatening not to concede (2), the healthcare system (1), the Supreme Court controversy (1), and climate change (1). Concerning the foreign policy agenda, the articles reference Russia (2), China (2), North Korea (1), Ukraine (1); and, remarkably, US-British relations obtain only one mention.

Matthew Syed (4 Oct. 2020) writes in The Times that "Biden offers the only hope of a route back towards sanity, towards the rule of law, towards an international alliance between free nations that can operate as the only meaningful check on the imperial ambitions of a newly assertive China". In the same vein, Henry Zeffman (3 Oct. 2020) argues that "Biden has a long political record of moderation", and an approach to political communication which "would surely not inflame a combustible situation".

Along these lines, the frame which most often crops up in the British press is concerned with Trump's aggressive, populist, and untruthful disposition (19 mentions), followed by Biden's depiction as a moderate, cautious, responsible though unassertive politician, who is staunchly loyal to his country's democracy and its institutions, and will do his utmost to reconcile and reunite the American people (13). Conversely, the frames emerging for Trump are his refusal to disavow white supremacists (5), and his repeated intimations that he will not accept a defeat in the election (5).

\subsection{Europe}

Of the 87 articles we analyzed, 74 are opinion articles and 13 are editorials. The UK has devoted the largest number of articles to the two debates in the time span we chose to gather our sample, namely 29 articles $(33,33 \%$ of the articles published by all four countries), followed by Spain with 28 articles $(32,18 \%)$, and Germany and France with 15 article each $(17,24 \%)$. These results bear out our first hypothesis that the British press would dedicate the greatest attention to the presidential debates between Trump and Biden.

Figure 1. Total number of articles dedicated to the debates by countries. 
Sintes Olivella, Marçal; Franch, Pere; Yeste-Piquer, Elena; Zilles, Klaus. Europe abhors Donald Trump.

The opinion on the 2020 US presidential elections and their candidates in the European newspapers.

American Behavioral Scientist, 2021. April 2. https://doi.org/10.1177/00027642211005534

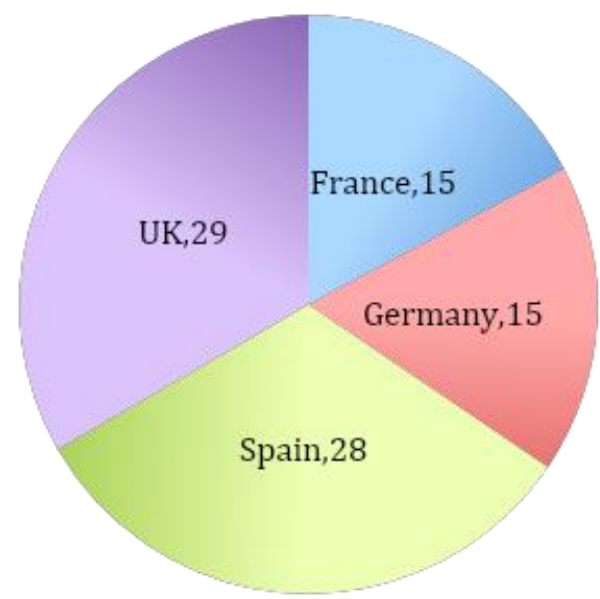

Source: Authors.

With respect to the tone employed to characterize the two candidates, among the total tally of representatives of the European press we examined 72 articles attribute a negative tone to Trump $(82,76 \%), 10$ articles are neutral in tone (11,49\%), 2 are positive $(2,30 \%)$, and $3(3,45 \%)$ are not classifiable.

Figure 2. The tone of the articles regarding the Republican candidate, Donald Trump.

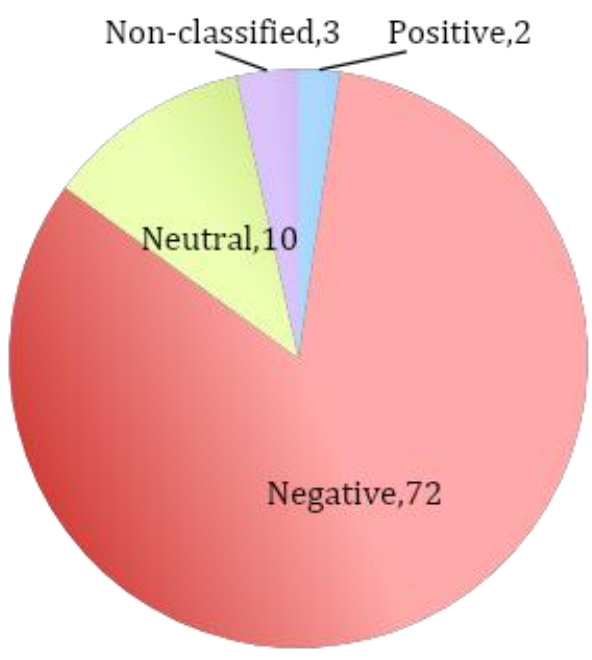

Source: Authors.

As for Biden, 20 of the references are negative in tone (22,99\%), 17 are neutral $(19,54 \%), 15$ are positive $(17,24 \%)$, and $21(24,13 \%)$ are not classifiable. Thus, our second hypothesis is partially confirmed in that the European press does indeed issue a manifestly negative appraisal of Donald Trump. However, in the case of Joe Biden, favorable appraisal does not prevail, as our hypothesis predicted. Many estimations of Biden are clearly negative or not classifiable. In fact, the French Le Figaro constitutes an outlier in the context of the European press in that its authors take a predominantly negative tone toward Biden while staying mostly neutral on Trump.

Figure 3. The tone of the articles regarding the Democratic candidate, Joe Biden. 


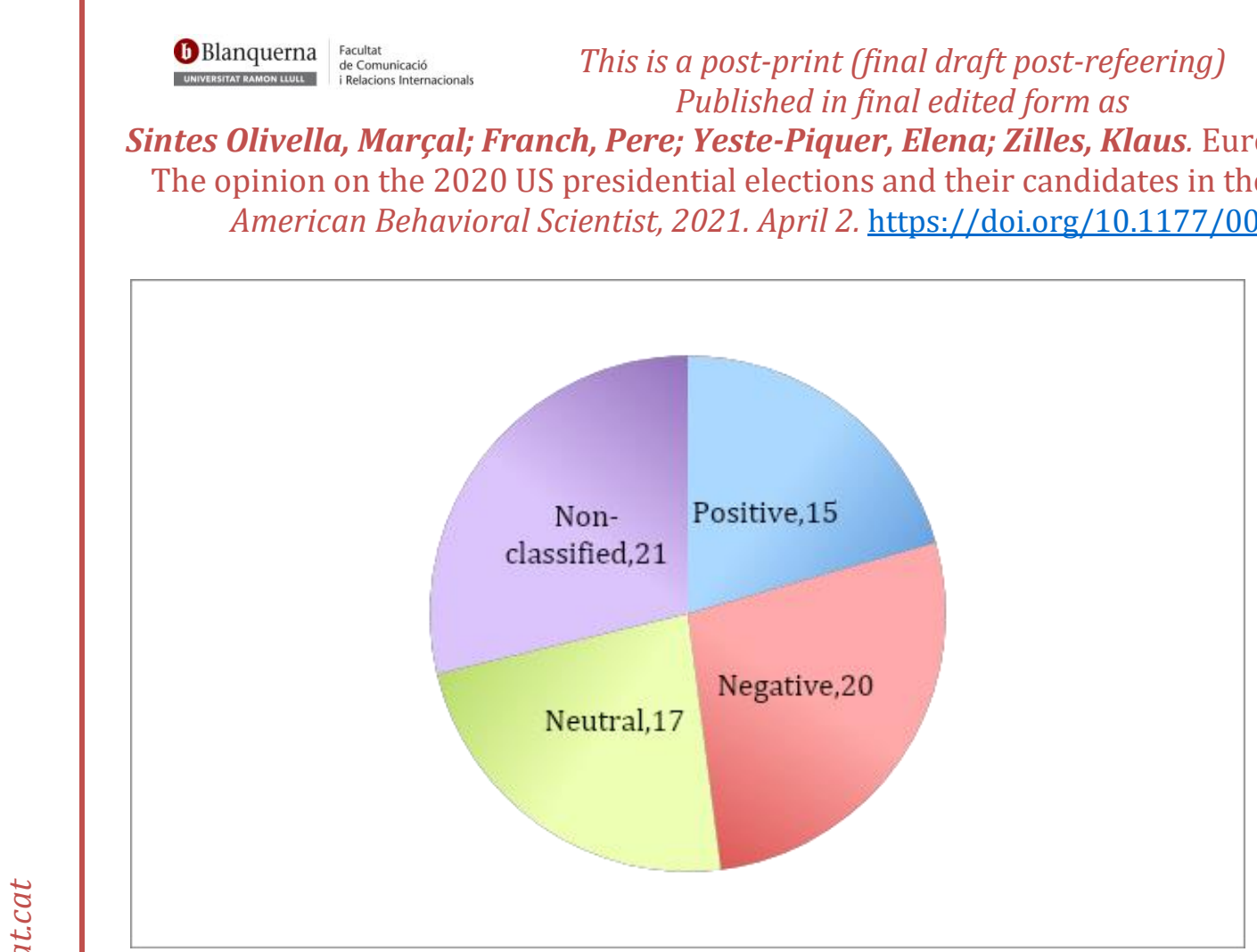

Source: Authors.

Among the predominant frames we have detected in our sample of the European press, Trump's aggressive, populist, and untruthful approach to politics and communication takes first place with 51 mentions (58,62\%), followed by Biden as a moderate, prudent, responsible, albeit weak politician, tough with a staunch commitment to US democracy, its institutions, and bringing the American people together. This frame emerges in 34 articles which corresponds to $39,08 \%$ of the total. The third most detected frame is Trump's contribution to the polarization and division of US society, which appears in 29 articles $(33,33 \%)$.

Henceforward, the frames with lesser, but still prominent presence, are: Trump displays reckless conduct over Covid-19 (28 mentions; 32,18\% of the total); Trump damages and diminishes US democracy and its institutions and denigrates the reputation of the US (14 mentions; 16,09\%); 12 mentions each go to Trump's refusal to distance himself from white supremacists, and his threats to reject the election results in the event of his defeat $(13,79 \%$ each). We counted 10 references to the assumption that neither candidate offers a palpable solution to the economic crisis, and that both Trump and Biden are going to perpetuate the isolationist and protectionist political course of the US, especially in economic policy. With 8 mentions $(9,20 \%)$, the controversy over Trump's tax dodging brings up the rear. In sum, our third hypothesis is borne out by the data as the overall framing of the European press manifestly portrays Trump as a politician with an abrasive, radical style who is bent on stoking the division among the American people.

Table 1. List of predominant frames emerging in the articles about the presidential debates.

\begin{tabular}{|l|l|}
\hline Frames & $\begin{array}{l}\text { Instances in the } \\
\text { articles (out of } \\
\text { the total) }\end{array}$ \\
\hline $\begin{array}{l}\text { Trump's political and communication style is aggressive, populist with a } \\
\text { penchant for dishonesty. }\end{array}$ & 51 \\
\hline $\begin{array}{l}\text { Biden is a moderate, prudent, and responsible politician, albeit unassertive, } \\
\text { though strongly committed to US democracy, to its institutions, and to uniting } \\
\text { the American people. }\end{array}$ & 34 \\
\hline Trump seeks to increase the polarization and division of US society. & 29 \\
\hline Trump displays reckless conduct over Covid-19. & 28 \\
\hline $\begin{array}{l}\text { Trump damages and diminishes US democracy, its institutions, and he } \\
\text { denigrate the reputation of the US. }\end{array}$ & 14 \\
\hline Trump avoids distancing himself from white supremacists. & 12 \\
\hline Trump will not accept the election outcome if he does not win. & 12 \\
\hline $\begin{array}{l}\text { Neither candidate offers a solution to the economic crisis. Both Trump and } \\
\text { Biden are going to perpetuate the isolationist and protectionist political course } \\
\text { of the US, especially in economic policy. }\end{array}$ & 10 \\
\hline
\end{tabular}


Sintes Olivella, Marçal; Franch, Pere; Yeste-Piquer, Elena; Zilles, Klaus. Europe abhors Donald Trump.

The opinion on the 2020 US presidential elections and their candidates in the European newspapers. American Behavioral Scientist, 2021. April 2. https://doi.org/10.1177/00027642211005534

Trump avoids paying his taxes.

8

Source: Authors.

The candidates' approach to political communication is an element that emerges in 50 out of the 87 articles that constitute the corpus of our study, which amounts to el 57,47\%. The main issues which dominate US political agenda, and which are referenced in our sample, are the US domestic politics, mentioned 167 times in the articles, whereas foreign policy only appears in 25 occasions. This result disproves our fourth hypothesis, which posited that the European press would prioritize international relations, and in particular, US-European affairs.

In particular, in the area of domestic issues, the predominant concern is the Covid-19 pandemic, which is referenced in 42 articles, which corresponds to $25,15 \%$ of the total references to US domestic issues (167), and $48,28 \%$ of the total of the articles that were analyzed. Further issues that were given priority in the articles are: the economy (27), which amounts to $31,03 \%$ of the 87 articles in our sample; racism (26; 29,89\%;), Trump's tax evasion (14, 16,09\%); Trump rejecting the election results (12; 13,79\%); climate change $(12 ; 13,79 \%)$; the Supreme Court nominations $(12 ; 13,79 \%)$; the healthcare system $(11: 12,64 \%)$, the investigation into Hunter Biden (8; 9,20\%), and immigration $(3 ; 3,45 \%)$.

Figure 4. Total numbers of domestic issues referenced in the articles.

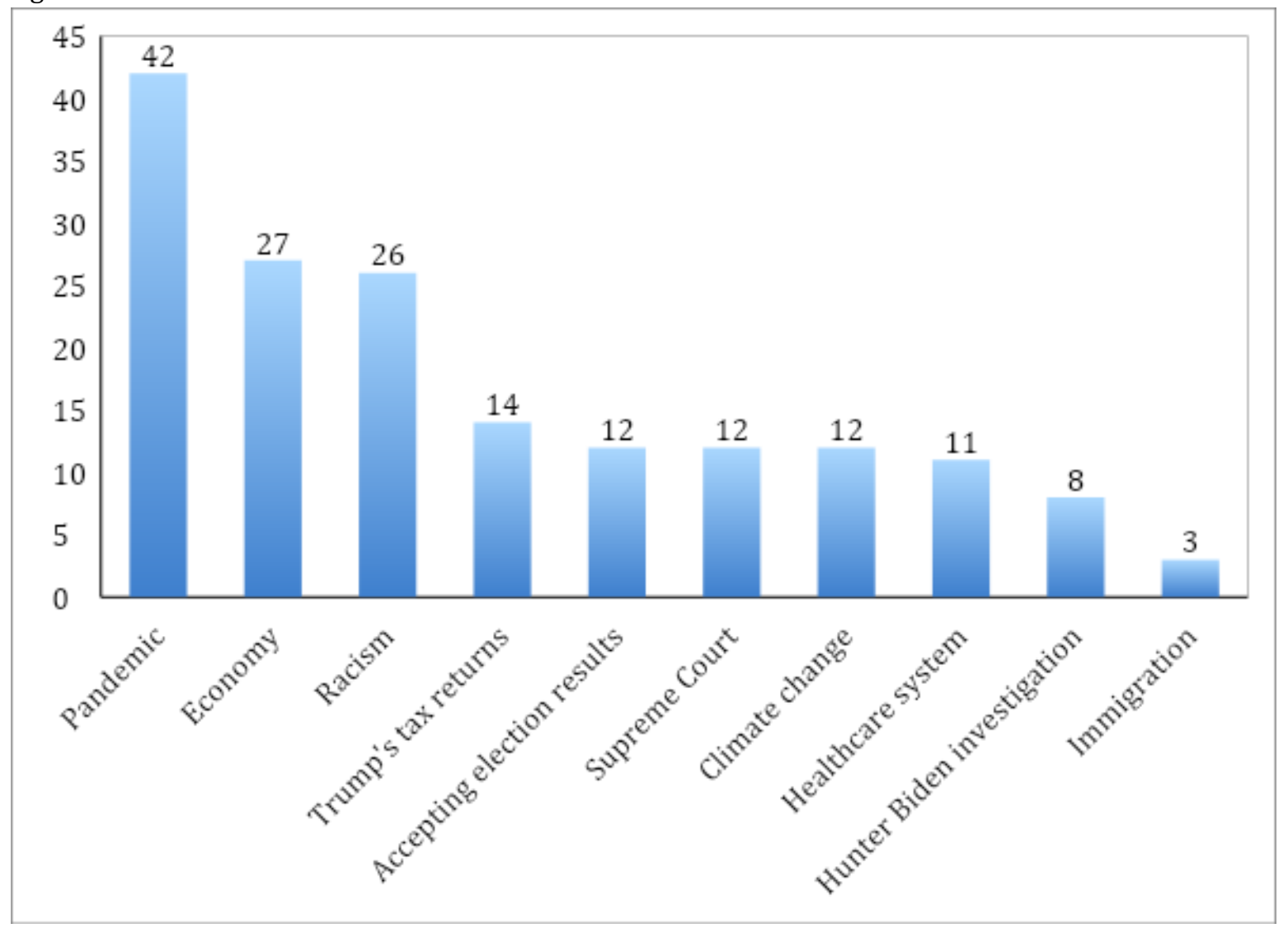

Source: Authors.

Although in the area of foreign policy and international affairs references are scarcer, US relations with China stand out from the rest with mentions in 10 articles $(11,49 \%$ of the total). Next are articles referencing Russia (7; 8,05\%). US-European relations feature in only 3 of the articles, and US-UK relations in only 2. There is one reference each to the papal encyclical "Fratelli Tutti", North Korea, and Ukraine. The picture that emerges is that references to US-European and US-British relations are merely residual, which disproves our hypothesis that the European press would give preferential treatment to their countries' dealings with the US.

\section{Conclusions}

The frames that we identified in the articles feature two of the four characteristics put forward by Entman 
Sintes Olivella, Marçal; Franch, Pere; Yeste-Piquer, Elena; Zilles, Klaus. Europe abhors Donald Trump.

The opinion on the 2020 US presidential elections and their candidates in the European newspapers. American Behavioral Scientist, 2021. April 2. https://doi.org/10.1177/00027642211005534

(2003): a) they define effects or conditions as problematic and c) they convey a moral judgment of those involved in the framed matter. Thus, after validating the heightened coverage the European press bestows on Trump, with Biden largely unattended, it follows that both in the editorials and the opinion articles a strikingly negative image of Trump materializes. This is because according to Entman, the framing of the news about Trump necessarily defines his comportment as problematic, which occasions a moral judgement on Trump, and, in turn, prompts a favorable verdict on Biden.

The European commentators emphasize that Trump is a leader who damages US institutions, devalues their prestige, and disparages US democracy and its international reputation: they provide an abundance of examples, of which the most frequently cited are his tax evasion, and his unwillingness to accept defeat, on which he has never yielded.

Beyond Trump's much bemoaned political discourse and communication style, commentators have also censured his moral character, variously dubbing him a demagogue, a liar, uncouth, aggressive, incendiary, and a populist who levels the charge of "fake news" at any news source that refuses to follow him down the rabbit hole of his alternate reality. Not stopping there, many journalists deplore his vanity, his narcissism, and his selfishness, all of which, in the end, amount to an approach to politics completely unencumbered by a moral conscience. The disastrous consequences of this lack of integrity and common decency resulted in an unprecedented healthcare crisis brought about by Trump's inaction to the Covid pandemic, which was exacerbated by his disdain for science and experts, and his unrelenting and unfounded claims of a Chinese conspiracy hatched to spread the virus across the globe. As if that were not enough, bewildered European commentators bore witness to Trump's consistent attempts at dividing and polarizing, and his insidious dog-whistles to his far-right white supremacist voters.

Biden, by contrast, is only seldom placed center stage in the European press (at least not during the time span that rendered the corpus of articles we have analyzed). We have made frequent allusions to his proverbial sense of responsibility, his moderation, and his prudence, as well as the democratic ethos that sets him apart from his opponent. His respectful, well-mannered (at times folksy) approach to interacting with others has earned him an undeserved reputation for being feeble and unassertive, which is often put down to his advanced age, which Trump has exploited by calling Biden "Sleepy Joe". Then again, most commentators never fail to point out Biden's honesty, his competence, his political experience, and his unwavering advocacy for unity and concord among his fellow Americans. Perhaps the best proof of his sensible, fact-based approach is his compliance with Covid safety measures like social distancing and wearing a face mask.

Much to our surprise, there was a conspicuous dearth of mentions of foreign affairs and international policies. When they do surface, they address future US-European cooperation and partnership, the ramifications the election outcome will have for the fight against climate change, and they mention Russia and China only in passing. When commentators express hope for a return to multilateral US foreign policies under Biden, it comes with a caveat that Biden's stance on international politics is perhaps only slightly less protectionist than Trump's.

The coverage of the US election campaign in the British and Spanish press is much more extensive than in the French and German press. In the case of the UK, this may be attributable to the cultural, linguistic, and historical ties to the US, as well as British hopes for a closer partnership with the US following Brexit. The conservative ideological affinity between Trump and Johnson may also play a role, though to confirm this hypothesis would go beyond the scope of this study. It merits pointing out that The Guardian, generally believed to hold a center-left media bias, affords a much wider coverage to the debates than the conservative Times. Predictably, the treatment Trump gets in The Guardian is nothing short of withering and derisive.

The two Spanish newspapers, both Madrid-based, display a much bigger interest in the debates than their French and German counterparts, and they are both extremely critical of Trump. In fact, the German and the French press coverage on the whole seemed more muted when compared to the obsessive fixation of the Spanish and British press with the US election process. Here, the two left-leaning media, The Guardian and El País surpass all the other newspapers in the number of articles dedicated to the issue, and in the negative tone in which they portray the incumbent candidate.

The results of our study allow us to assert that the newspapers with a progressive bias (Le Monde, 
Sintes Olivella, Marçal; Franch, Pere; Yeste-Piquer, Elena; Zilles, Klaus. Europe abhors Donald Trump.

The opinion on the 2020 US presidential elections and their candidates in the European newspapers. American Behavioral Scientist, 2021. April 2. https://doi.org/10.1177/00027642211005534

Süddeutsche Zeitung, El País, and The Guardian) are much more disapproving of Trump than the newspapers with a conservative bias (Le Figaro, Frankfurter Allgemeine Zeitung, El Mundo, and The Times).

The present study is among the few that expressly concentrate on the manner in which opinion articles in prestigious quality newspapers in Europe cover US politics and politicians. There is much less research on framing in opinion pieces and editorials than research that examines straight out news reporting. We consider this study a good starting point which could be extended to other European countries (all $27 \mathrm{EU}$ member states, or even all countries on the continent), or to other media, such as audiovisual, digital, or social media. Indeed, additional aspects might be included that are affected by agenda-setting, framing or the different media systems. Also, it would be worthwhile to extend the time frame of the study -over several years, for instance- in order to determine whether the issues and the frames that have emerged are subject to change over time, given that their nature is dynamic by definition. These, of course, are novel approaches which, regretfully, go beyond the scope of this article.

\section{Referencias}

ACPM, L'Alliance pour les Chiffres de la Presse et des Médias (2020). Classement Diffusion Presse Quotidienne Nationale 2019-2020. Retrieved from

https://www.acpm.fr/Les-chiffres/Diffusion-Presse/Presse-Pavante/Presse-Quotidienne-Nationale.

AIMC, Asociación para la Investigación de Medios de Comunicación (2020). Audiencia General de Medios. Retrieved from https://reporting.aimc.es/index.html\#/main/diarios.

Albright, M. (2018). Fascism: A warning. Harper Collins.

Alitavoli, R. (2020). Framing the news on the Syrian War: A comparative study of antiwar.com and cnn.com editorials. Media War and Conflict, 13(4), 487-505.

https://doi.org/10.1177/1750635219850326

Ardèvol-Abreu, A. (2015). Framing o teoría del encuadre en comunicación. Orígenes, desarrollo y panorama actual en España. Revista Latina de Comunicación Social, 70, 423-450.

http://doi.org/10.4185/RLCS-2015-1053

Bardin, L. (1977). L'analyse de contenu. Paris. Presses Universitaires de France.

Bassets, Ll. (2020). Fiel a sí mismo. El País, 1 October.

Basterra, F. G. (2020). La elección envenenada. El País, 5 October.

Baverez, N. (2020). De la corruption de la démocratie en Amérique. Le Figaro, 5 October.

Berelson, B. (1952). Content analysis in Communication Research. Glencoe. Free Press.

Biden, J. (2008). Promises to keep: on life and politics. Random House.

Burns, N., \& Lute, D. (2019). NATO at seventy: an alliance in crisis. Belfer Center

for Science and International Affairs, Harvard Kennedy School.

Retrieved from https://www.hks.harvard.edu/publications/nato-seventv-alliance-crisis

Caño, A. (2020). Manual Breve para nuestro tiempo. El País, 23 October.

Chadwick, A. (2013). The hybrid media system: politics and power. Oxford University Press.

Cohen, B. C. (1963). The press and foreign policy. Princeton University Press.

Dahmen, N.S. (2010). Construction of the Truth and Destruction of a Little Million Pieces. Framing in the editorial response to the James Frey case. Journalism Studies, 11(1), 115-130.

https://doi.org/10.1080/14616700903172080 
Sintes Olivella, Marçal; Franch, Pere; Yeste-Piquer, Elena; Zilles, Klaus. Europe abhors Donald Trump.

The opinion on the 2020 US presidential elections and their candidates in the European newspapers. American Behavioral Scientist, 2021. April 2. https://doi.org/10.1177/00027642211005534

De la Serna, V. (2020). Periodismo, Trump, coronavirus. El Mundo, 4 October.

Druckman, J. \& Parkin, M. (2005). The impact of media mias: how editorial slant affects voters. The Journal of Politics, 67(4), 1.030-1.049.

https://doi.org/10.1111/i.1468-2508.2005.00349.x

Entman, R.M. (1993). Framing: toward clarification of a fractured paradigm. Journal of Communication, 43(4), 51-58.

https: //doi.org/10.1111/i.1460-2466.1993.tb01304.x

Entman, R.M. (2003). Cascading activation: contesting the White House's frame after 9/11. Political

Communication, 20(4), 415-432.

https://doi.org/10.1080/10584600390244176

Fabry, E. (2020). La guerre commerciale, un choix assumé. Le Monde, 25 October.

Ford, R. (2020). Sous le patchwork en folie de l'Amérique, un substrat de glace et de silence nous immobilise. Le Monde, 23 October.

Funkhouser G. R. (1973). Trends in media coverage of the issues of the '60s. Journalism Quarterly, 50(3), 533-538.

https://doi.org/10.1177/107769907305000317

Garza, M.M. (2017). Framing Mexicans in Great Depression Editorials: Alien Riff-Raff to Heroes. American Journalism, 34(1), 26-48. https://doi.org/10.1080/08821127.2016.127521

Gélie, P. (2020). Des coups pour rien. Le Figaro, 29 September.

Gélie, P. (2020). Le Houdini des sondages. Le Figaro, 27 October.

Green, Ll. (2020). Trump v Biden in the first 2020 presidential debate: our panelists' verdict. The Guardian, 30 September.

Ha, J.S. (2017). Tailoring the Arab Spring to American values and interests: A framing analysis of US elite newspapers' opinion pieces. International Communication Gazette, 79(3), 276-297.

https://doi.org/10.1177/1748048516689178

Ha, J.S. (2015). "Arab Spring is a Wake-up call for Kim Jong-il". A framing analysis of South Korean opinion pieces. Journalism Practice, 9(5), 741-759. https://doi.org/10.1080/17512786.2014.995915

Hallin, D. C., \& Mancini, P. (2004). Comparing media systems: three models of media and politics. Cambridge University Press.

Hidalgo, M. (2020). En el cieno. El Mundo, 2 October.

Iyengar, S. (1990). The accessibility bias in politics: television news and public opinion. International Journal of Public Opinion Research, 2(1), 1-15.

https://doi.org/10.1093/iipor/2.1.1

Janusch, H., \& Mucha, W. (2017). America first: power and geopolitics in US trade policy under president Trump. S\&F Sicherheit und Frieden, 35(3), 8-12.

https://doi.org/10.5771/0175-274x-2017-3-8

Jotzo, F., Depledge, J., \& Winkler, H. (2018). US and international climate policy under President Trump. Climate Policy, 18(7), 813-817.

https://doi.org/10.1080/14693062.2018.1490051 
Sintes Olivella, Marçal; Franch, Pere; Yeste-Piquer, Elena; Zilles, Klaus. Europe abhors Donald Trump.

The opinion on the 2020 US presidential elections and their candidates in the European newspapers. American Behavioral Scientist, 2021. April 2. https://doi.org/10.1177/00027642211005534

Kahn, K. F., \& Kenney. P. J. (2002): The Slant of the News. American Political Science Review, 96, 2, 381-394. http://dx.doi.org/10.1017/S0003055402000230

Kemp, L. (2017). US-proofing the Paris climate agreement. Climate Policy, 17(1), 86-101. https://doi.org/10.1080/14693062.2016.1176007

Kettle, M. (2020). The Trump-Biden debate revealed the dangers of Britain's 'special relationship'. The Guardian, 30 September.

Koeth, W. (2019). From "Global Europe" to trade defence: the EU responds to Trump and China. European Institute of Public Administration. Retrieved from https://www.eipa.eu/wp-content/uploads/2019/01/From-Global-Strategy$\underline{\text { to-trade-defence.pdf }}$

Krippendorff, K. (2004). Content analysis. An introduction to its methodology. Thousand Oaks, Sage.

Kornelius, S. (2020). Das kranke Land. Süddeutsche Zeitung, 4 October.

Lang, G. E., \& Lang, K. (1981). Watergate. An exploration of the agenda-building process. In C.G. Wilhoit, C. G. \& De Bock, H. (eds), Mass Communication Review Yearbook 2, 447-469. Sage Publications.

Le Monde (Editorial board). (2020). Un débat inquiétant pour la démocratie américaine. Le Monde, 1 October.

Le Monde (Editorial board). (2020). Aux États-Units, une cour suprême républicaine. Le Monde, 29 October.

Leonnig, C. D., \& Rucker, P. (2020). A very stable genius: Donald J. Trump's testing of America. Penguin Press.

Leparmentier, A. (2020). Joe Biden et les illusions commerciales européennes. Le Monde, 30 September.

Levingston, S. (2029). Barack and Joe: the making of an extraordinary partnership. Hachette Books.

Lippmann, W. (1922). Public opinion. Harcourt, Brace and Company.

Liu, B. (2010). Sentiment Analysis and Subjectivity. Handbook of natural language processing, 627-666. Chicago, University of Illinois.

MacGregor, J. R. (2019). Trump. The biography: from businessman to 45th president of the United States: Insight and analysis into the life of Donald J. Trump. CAC Publishing.

Mandeville, L. (2020). Meme le Covid ne peut pas changer Trump. Le Figaro, 6 October.

Mandeville, L. (2020). Deux campagnes et deux philosophies que tout oppose. Le Figaro, 26 October.

Mayhew, F. (2020). National newspaper ABCs: Daily Mail closes circulation gap on Sun to 5,500 copies.
Press
Gazette.
March,
19 ,
2020.
Retrieved

fromhttps://www.pressgazette.co.uk/national-newspaper-abcs-daily-mail-closes-

circulation-gap-on-sun-to-5 $\underline{500 \text {-copies/ }}$

McCombs, M. (2004). Setting the agenda. Themass media and public opinion. Polity Press.

McCombs, M., \& Shaw, D. L. (1972). The agenda-setting function of mass media. Public Opinion Quarterly, 36(2), 176-187.

https://doi.org/10.1086/267990

McCombs, M., Llamas, J. P., López-Escobar, E., \& Rey, F. (1997). Candidate images in Spanish elections: second level agenda-setting effects. Journalism and Mass Communication Quarterly, 74(4), 703-717.

https://doi.org/10.1177/107769909707400404 
Sintes Olivella, Marçal; Franch, Pere; Yeste-Piquer, Elena; Zilles, Klaus. Europe abhors Donald Trump.

The opinion on the 2020 US presidential elections and their candidates in the European newspapers. American Behavioral Scientist, 2021. April 2. https://doi.org/10.1177/00027642211005534

McCombs, M., \& Ghanem, S. I. (2001). The convergence of agenda setting and framing. In Reese, S. D., Gandy, O. H., Jr., Grant, A. E. (Eds.). Framing public life: perspectives on media and our understanding of the social world. Roudledge, 67-82.

McCombs, M, \& Guo, L. (2014). Agenda-setting influence of the media in the public sphere. In Fortner, R. S., Fackler, P. M. (eds). The handbook of media and mass communication Theory. John Wiley \& Sons, 249-268. https://doi.org/10.1002/9781118591178.ch14

Medhat, W.; Hassan, A. \& Korashy, H. (2014): Sentiment analysis algorithms and applications: A survey. Ain Shams Engineering Journal, 5(4), 1.093-1.113.

http://dx.doi.org/10.1016/i.asej.2014.04.011

Mudde, C. (2020). How does the rest of the world feel about the US election? Like the US, polarized. The Guardian, 28 October.

Muñoz Molina, A. (2020). Otro noviembre. El País, 25 October.

Norris, P., \& Inglehart, R. (2019). Cultural backlash: Trump, Brexit, and authoritarian populism. Cambridge University Press.

Osnos, E. (2020). Joe Biden: the life, the run, and what matters now. Scribner.

Palacio, A. (2020). Donald Trump, lo que se queda y lo que se va. El Mundo, 3 October.

Polyakova, A., \& Haddad, B. (2019). Europe alone: what comes after the transatlantic alliance. Foreign Affairs, January-February.

Retrieved from $\underline{\text { https://www.foreignaffairs.com/articles/europe/2019-06-11/europe-alone }}$

Price, V., \& Tewksbury, D. (1997). News values and public opinion: A theoretical account of media priming and framing. In Barnett, G. A., Boster, F. J. (Eds.). Progress in communication sciences: advances in persuasion 13, 173-212. Ablex Publishing Corporation.

Prose, F. (2020). Has Trump learned anything from Covid-19? Absolutely not. The Guardian, 6 October.

Renton, D. (2020). When Trump defends armed rightwing gangs, his rhetoric has echoes of fascism. The Guardian, 1 October.

Ross, A. (2020). Biden tut sich schwer. Frankfurter Allgemeine Zeitung, 30 September.

Scheufele, D. A. (2000). Agenda-setting, priming, and framing revisited: Another look at cognitive effects of political communication. Mass Communication \& Society, 3(2-3), 297-316. https://doi.org/10.1207/s15327825mcs032307

Semetko, H. A. \& Valkenburg, P. M. (2000). Framing European Politics: A content Analysis of Press and Television News. Journal of Communication, 50, 2, 93-109.

http://doi.org/10.1111/i.1460-2466.2000.tb02843.x

Sniderman, P. M., \& Theriault, S. M. (2004.). The structure of political argument and the logic of issue framing. Studies in Public Opinion, 133-165.

https://doi.org/10.2307/i.ctv346px8.9

Sperling, J., \& Webber, M. (2019). Trump's foreign policy and NATO: Exit and voice. Review of International Studies, 45(3), 511-526.

https://doi.org/10.1017/s0260210519000123

Stelter, B. (2020). Hoax: Donald Trump, Fox News, and the dangerous distortion of truth. One Signal Publishers-Atria.

Syed, M. (2020). Get well soon - not just Trump, but America. The Times, 4 October. 
Sintes Olivella, Marçal; Franch, Pere; Yeste-Piquer, Elena; Zilles, Klaus. Europe abhors Donald Trump.

The opinion on the 2020 US presidential elections and their candidates in the European newspapers. American Behavioral Scientist, 2021. April 2. https://doi.org/10.1177/00027642211005534

Taboada, M., Brooke, J., Tofiloski, M., Voll, K. \& Stede, M. (2011). Lexicon-Based Methods for Sentiment Analysis. Computational Linguistics, 37, 2. 267-307. https://doi.org/10.1162/COLI_a_00049

The Guardian (Editorial). (2020). The Guardian view on the US presidential debate: a bad night for the world. The Guardian, 2 October.

The Guardian (Observer editorial). (2020). The Observer view on Donald Trump's coronavirus infection. The Guardian, 5 October.

The Times. (2020). Disunited States. The Times, 1 October.

The Times. (2020). The Times view on the US presidential debate: Trump's Tactics. The Times, 24 October.

Thelwall, M. Buckley, K., Paltoglu, G., Caid, D. \& Kappas, A. (2010). Sentiment in short Strength Detection Informal Text. Journal of the American Society for Information Science and Technology, 61(12), 2.544-2.558. http://dx.doi.org/10.1002/asi.21416

Thomaß, B.; \& Horz, Ch. (nd). Germany. Media Landscapes. Retrieved from:

https://medialandscapes.org/country/germany/media/print

Tobitt, Ch. (2020). Pamco audience data: The Sun is the most-read UK news brand as sector sees strong year on year growth. Press Gazette. December, 9, 2020. Retrieved from https://www.pressgazette.co.uk/pamco-uk-national-news-websites-strong-growth-post-covid/

Trump, M. L. (2020). Too much and never enough: how my family created the world's most dangerous man. Simon \& Schuster.

Urpelainen, J., \& Van de Graaf, T. (2018). United States non-cooperation and the Paris agreement. Climate Policy, 18(7), 839-851.

https://doi.org/ 10.1080/14693062.2017.1406843

Weber, R. P., (1990). Basic content analysis. Sage.

Welfens, P. J. J. (2019). The global Trump: structural US populism and economic conflicts with Europe and Asia. Springer Nature.

https://doi.org/10.1007\%2F978-3-030-21784-6

Wilson, G. K. (2017). Brexit, Trump and the special relationship. The British Journal of Politics and International Relations, 19(3), 543-557.

https://doi.org/10.1177/1369148117713719

Wolff. M. (2019). Siege: Trump under fire. Henry Holt and Company.

Wolff. M. (2018). Fire and fury: inside the Trump White House. Henry Holt and Company.

Woodward, B. (2018). Trump in the White House. Simon \& Schuster.

Woodward, B. (2020). Rage. Simon \& Schuster.

Zaschke, C. (2020). Strategie des Lächelns. Süddeutsche Zeitung, 30 September.

Zeffman, H. (2020). Trump v Biden may well be settled in court or on the streets. The Times, 3 October.

\section{Author Biographies}

Marçal Sintes-Olivella is professor and Director of the Research Institute at the School of Communication and International Relations Blanquerna-Universitat Ramon Llull (Barcelona). His research interests 
Sintes Olivella, Marçal; Franch, Pere; Yeste-Piquer, Elena; Zilles, Klaus. Europe abhors Donald Trump.

The opinion on the 2020 US presidential elections and their candidates in the European newspapers. American Behavioral Scientist, 2021. April 2. https://doi.org/10.1177/00027642211005534

mainly focus on media, politics and power. He is the former Director of Center for Contemporary Culture of Barcelona (CCCB). He contributes as an analyst to a different media in Spain.

Pere Franch is professor of Journalism and International Relations and director of the master's degree in International Journalism at the School of Communication and International Relations BlanquernaUniversitat Ramon Llull (Barcelona). His research interests mainly focus on media, rhetoric and political communication.

Elena Yeste-Piquer is professor and Coordinator of the Degree in Journalism and Corporate Communication at Blanquerna School of Communication and International Relations. She is Coordinator of the Master's Degree in Political and Social Communication and the Master's Degree in Advanced Journalism, and the editor in chief of the journal Tripodos. Her research interests focus on journalism, political communication and collective memory.

Klaus Zilles is an associate professor at the Blanquerna School of Communication Studies and International Relations at Ramon Llull University in Barcelona, Spain. He holds a Ph.D. in English and German Philology from the University of Heidelberg. He was the co-coordinator of the Blanquerna International Conference on Communication and Reality from 2011 to 2015. Klaus Zilles's writes on literary criticism, literature and film, identity politics in the media and, of late, on social media, disinformation and metacognitive awareness. 